\title{
In situ measurement of recruitment, mortality, growth, and fecundity of Capitella sp. (Annelida: Polychaeta)
}

\author{
Pei-Yuan Qian, Fu-Shiang Chia
}

Department of Biology, The Hong Kong University of Science and Technology, Clear Water Bay, Kowloon, Hong Kong

\begin{abstract}
The development of a marking method using a vital dye enabled us to study the in situ recruitment, mortality, growth, and reproduction of Capitella sp. at 2 mud flats (the Grappler Inlet and Bamfield Inlet) near the Bamfield Marine Station, British Columbia, Canada. It was found that (1) recruitment at the 2 sites did not correspond with the larval abundance in the plankton, (2) juvenile mortality was size-dependent, and (3) juvenile mortality was directly related to the number of predators present in the habitats. These results suggest that juvenile mortality by predation is a major factor affecting the recruitment and population dynamics of Capitella $\mathrm{sp}$. at our study sites. Marked siblings reared in experimental trays that were placed in the natural habitats grew at a rate similar to that of laboratory-reared specimens; both reached sexual maturity in $3.5 \mathrm{mo}$. Fecundity, egg size, and egg energy content, measured in situ, varied greatly, corresponding to our previous laboratory findings on the same species.
\end{abstract}

KEY WORDS: Marking technique - In situ juvenile mortality - Recruitment - Growth - Reproductive characteristics Capitella sp.

\section{INTRODUCTION}

Field experiments dealing with recruitment of marine infaunal species have been difficult to conduct because of the lack of an appropriate method of sampling newly settled juveniles and of determining such things as differential mortality of post-settling stages, growth rate, and reproduction. To date, studies on recruitment and population dynamics of polychaetes have focused mainly on relationships between population density and environmental factors such as quality and quantity of food, predation, and substrate disturbances (Tenore 1981, 1983, Kent \& Day 1983, Chesney \& Tenore 1985, Oliver \& Slattery 1985, Tamaki 1985 , Tenore \& Chesney 1985, Levin \& Creed 1986, Beukema 1987) and on the impact of recruit mortality (Williams 1980, Levin 1981, Commito 1982, Gallagher et al. 1983, Luckenbach 1984, Woodin 1985, Watzin 1986). To the best of our knowledge, mortality, growth, and reproduction have not been determined for any marine polychaetes in situ.

On the other hand, many previous studies have examined the environmental impacts on growth, reproduction, and population dynamics of opportunistic polychaete species such as Capitella capitata (Tenore \& Chesney 1985, Grémare et al. 1989, Qian \& Chia 1991, 1992a, b), Polydora ligni (Zajac 1986), and Streblospio benedicti (Levin \& Creed 1986, Levin \& Huggett 1990, Levin et al. 1991). One of the usual criticisms is that laboratory data are unsuited for use in 'field situations'. However, many aspects of bioenergetics can only be studied in controlled laboratory conditions. Findings in this area have yet to be verified with data from the field. In this study, we report the results of in situ measurements of recruitment, postlarval stage mortality, growth, and fecundity of Capitella sp. and compare the data with that obtained in laboratory experiments. This study became possible because we have developed a method of successfully marking polychaetes with a vital dye.

\section{MATERIALS AND METHODS}

Study sites. The studies were conducted at 2 intertidal mudflats near the Bamfield Marine Station, Brit- 
ish Columbia, Canada. One was located at the head of Bamfield Inlet $\left(48^{\circ} 49^{\prime} 50^{\prime \prime} \mathrm{N}, 125^{\circ} 11^{\prime} 53^{\prime \prime} \mathrm{W}\right)$ and the other in Grappler Inlet ( $48^{\circ} 49^{\prime} 30^{\prime \prime} \mathrm{N}, 125^{\circ} 07^{\prime} 45^{\prime \prime} \mathrm{W}$ ) (Fig. 1). These sites were chosen because they are populated with Capitella sp. and because both sites are similar in intensity of wave action, physical disturbance, sediment grain size, water temperature, salinity, and depth (Rumrill 1987). A major difference between the 2 sites is that the infaunal polychaete community at Grappler Inlet was dominated by Capitella sp. whereas that at Bamfield Inlet was dominated by spionids.

It should be pointed out that juveniles and adults of Capitella sp. collected from the intertidal mudflat in this study have been considered as the same species based on findings in our laboratory experiments (Qian \& Chia 1991, 1992a, b). Variations in reproductive characteristics among individuals from Grappler Inlet have been discussed in Qian \& Chia (1992b). The individuals used for marking experiments and for studies

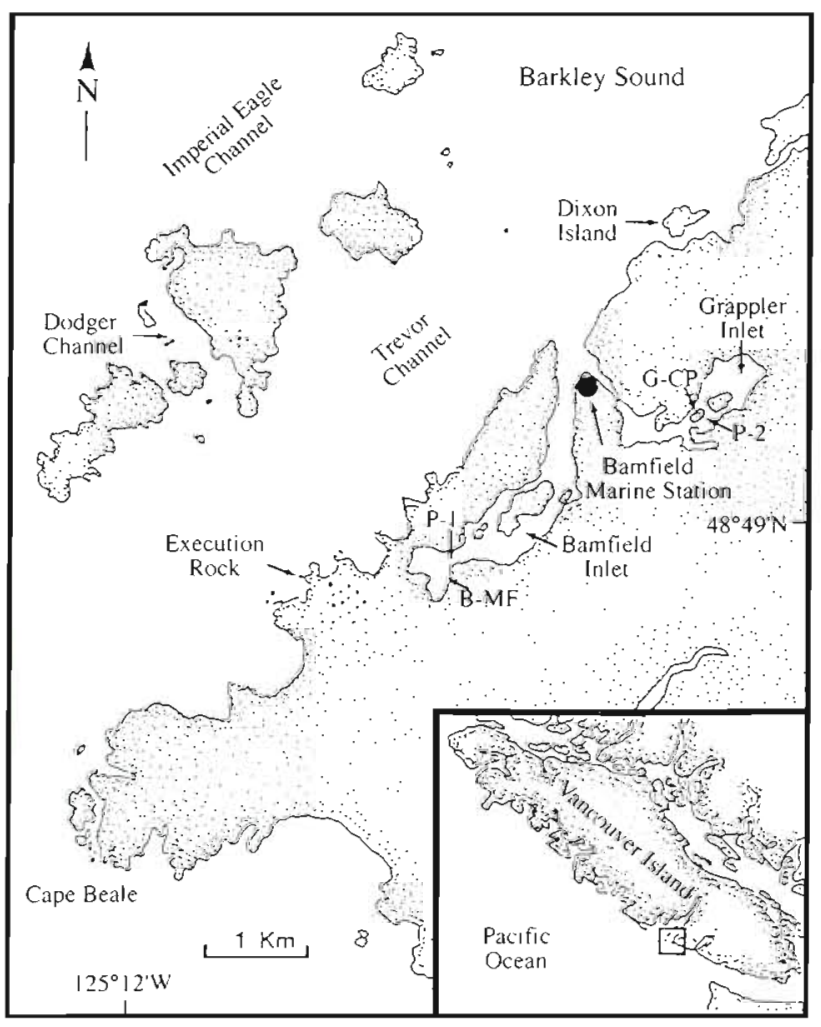

Fig. 1 Sampling sites in Barkley Sound, Vancouver Island, British Columbia, Canada. $\mathrm{P}_{1} \& \mathrm{P}_{2}$ : plankton sampling sites; B-MF: mudflat at Bamfield Inlet where experimental trays and cages were placed; G-CP: location of intertidal population of Capitella sp. at Grappler Inlet where benthic samples were collected monthly and where growth, mortality and fecundity of marked siblings were measured in situ. (Map modified from Roland 1980) of in situ mortality, growth, and reproduction, however, were the sibling individuals of a single worm from laboratory populations.

Larval abundance. Planktonic Capitella larvae were sampled every 2 to $4 \mathrm{wk}$ at both sites. Samples were collected from a depth of 2 to $3 \mathrm{~m}$ using a $125 \mu \mathrm{m}$ mesh plankton net 2 to $3 \mathrm{~h}$ before the daytime high tide. The plankton net was towed for 5 to $10 \mathrm{~min}$ from a $4 \mathrm{~m}$ vessel travelling at approximately 2 knots. The amount of water passing through the net was calculated using a flow meter positioned at the net opening. Plankton samples were brought to the laboratory immediately after collection and sorted live in a Bogorov tray. Larval abundance was expressed as number of larvae per $\mathrm{m}^{3}$ of water. Larval abundances at the 2 sites were compared using Kendall's coefficient of rank correlation test (Zar 1984).

Although it is difficult to identify larvae of Capitella spp., we have been able to separate 3 kinds of capitellid larvae found in plankton samples in our study areas, according to their size, color, general morphology, and developmental stages of larvae first appearing in plankton. This became possible only after intensive laboratory rearing experiments and observation of polychaete larvae in plankton for 4 yr. All larvae considered in this study should be of the same species although developmental stages of these larvae may vary from month to month.

In situ measurement of recruitment. The abundance of infaunal Capitella sp, at the Grappler Inlet site was estimated by sampling quadrats $(5 \times 5 \mathrm{~cm}$ at 8 to $10 \mathrm{~cm}$ depth) at 3 points $(0,7.5$, and $15 \mathrm{~m})$ along each of three $15 \mathrm{~m}$ transects parallel with the water line (high, middle, and low intertidal levels). Three samples were taken from each point. All samples were sieved carefully through a $200 \mu \mathrm{m}$ mesh, the worms retained were counted, and their density was expressed as number of individuals per $\mathrm{m}^{2}$. The percentage of juveniles (individuals with no visible gonads or genital spines) in each sample was calculated.

Experimental trays were constructed by dividing a plastic water tub $(45 \times 30 \times 15 \mathrm{~cm})$ into 6 parts (each an experimental tray) of equal size with wooden boards Two tubs with 12 experimental trays $(15 \times 15 \times 15 \mathrm{~cm})$ were placed along the transect line in the mid-intertidal region at each site. The surface of each tray was $2 \mathrm{~cm}$ above the mudflat surface. Each tray contained $12 \mathrm{~cm}$ of mud which was collected locally and sieved through a $200 \mu \mathrm{m}$ mesh in situ at the beginning of the experiments to eliminate large potential predators and competitors. All trays were left in the field for 2 to $3 \mathrm{wk}$, then brought back to the laboratory where the mud in each tray was sieved through a $200 \mu \mathrm{m}$ mesh, and all Capitella juveniles and other invertebrates were counted under a dissecting microscope. These experi- 
ments were conducted during the peak season of Capitella settling (i.e. April to August at Grappler Inlet and May to July at Bamfield Inlet).

Worms from the experimental trays were transferred to a glass Petri dish and relaxed in a mixture of equal parts of $0.36 \mathrm{M} \mathrm{MgCl}_{2}$ and seawater. The body diameter $(D)$ at the fifth setiger and body length $(L)$ of each worm was measured under a dissecting microscope with the aid of an ocular micrometer. Finally, body volume $(V)$ of each individual was calculated according to the equation $V=\pi(D / 2)^{2} L$, assuming that individuals were cylindrical in shape.

Marking sibling juveniles with vital dye. A stock solution of dye was made by adding $500 \mathrm{mg}$ of neutral red to $100 \mathrm{ml}$ of $0.45 \mu \mathrm{m}$ filtered seawater, stirring gently for $3 \mathrm{~min}$, and filtering with $25 \mu \mathrm{m}$ filter paper. This stock solution was stored under dark, cold $\left(4^{\circ} \mathrm{C}\right)$ conditions. Juveniles used for the experiments were placed in small Petri dishes $(3.5 \mathrm{~cm}$ in diameter) containing 3 to $4 \mathrm{ml}$ of filtered seawater $(0.45 \mu \mathrm{m})$. Five to seven drops of the stock solution were added to the Petri dish. Worms were stained for $2 \mathrm{~min}$ and washed twice by transferring them to a Petri dish containing filtered seawater $(0.45 \mu \mathrm{m})$. The actual duration of staining, however, was dependent on the worm's size; larger worms were treated for a longer period of time. Observations have indicated that the staining treatment had no effect on larval survival and growth. Within $72 \mathrm{~h}$, there were no significant differences in embryo and/or larval survival rates between stained and unstained individuals for the following organisms: 3-setiger larvae of Polydora ligni, trochophore larvae of Polynoid sp., 3-setiger larvae of Nereis vexillosa, trochophores of Spirorbis sp., embryos and trochophore larvae of Capitella sp. Our experiments also showed that, within $72 \mathrm{~h}$, stained and unstained $P$. ligni larvae had the same growth rate. Both stained and unstained juveniles showed no difference in growth rate and development and became sexually mature at the same time. The adults developed from those stained and unstained individuals produced similar numbers of eggs. The details of these experiments have been given elsewhere (Qian 1991, unpubl.).

Mortality and growth. Between 80 and 100 sibling juveniles of a single spawn of a single worm marked with neutral red were placed in the experimental trays as described above. Six to twelve trays were placed in the mid-intertidal region at both sites for 2 to $3 \mathrm{wk}$ before being brought back to the laboratory. Marked worms were recovered from each tray by resieving the mud through a $200 \mu \mathrm{m}$ mesh. In situ mortality of worms of different size (age) classes was estimated as a percentage of marked worms remaining at the end of each experimental interval ( 2 to $3 \mathrm{wk}$ ). Effect of age on juve- nile mortality was tested with the Mann-Whitney test (Zar 1984).

To determine the in situ growth rate, the body size and number of setigers of more than 30 marked sibling individuals were determined at the beginning of the experiments. At the end of each interval, at least 30 individuals from those marked siblings recovered from the experimental trays were randomly selected and measured. Prior to measurement, the worms were relaxed in a mixture of equal parts of $0.36 \mathrm{M} \mathrm{MgCl}_{2}$ and seawater and then measured with the aid of a microscope equipped with an ocular micrometer. Undamaged worms were returned to the trays. These experiments were continued until the worms became sexually mature and released eggs in their tubes.

Impact of predation on juvenile mortality. Four mud core samples (each core $15 \times 15 \times 12 \mathrm{~cm}$ ) were collected from both sites; care was taken to minimize the disturbance to the stratification and the infaunal organisms Each mud sample was immediately placed in an experimental tray as described above. One hundred sibling juveniles marked with neutral red were then placed in each experimental tray. Another 4 control trays were filled with the sieved mud $(<200 \mu \mathrm{m})$ and 100 marked worms were added to each. All 12 experimental trays were placed side by side in a random arrangement at the same intertidal level of the mid-intertidal region at the Bamfield Inlet site for $9 \mathrm{~d}$ before being brought back to the laboratory. Marked worms were then recovered from each tray by resieving the mud through a $200 \mu \mathrm{m}$ mesh sieve. The potential infaunal predators (polychaetes) from each tray were also recovered and identified. Effects of predation on in situ mortality of worms was estimated as the number of marked worms lost per day. To simplify the statistical analysis, all predator species were considered equal in terms of their predation pressures on the Capitella sp. and, thus, the numbers of all predator species were pooled to obtain the total number of predators in each tray. The 1-way ANOVA test was used to determine the effect of predation on juvenile mortality (Zar 1984).

Fecundity, egg size, and egg energy content. After 3.5 mo, marked individuals started to lay eggs. Because the eggs of a spawning individual were attached to the inner walls of its tube by mucus, it was relatively easy to determine fecundity (i.e. number of eggs released per spawn). In the laboratory, eggs were separated from the tube with dissecting needles and counted under a dissecting microscope.

A total of 20 to 30 eggs were randomly selected, mounted on a slide, and the long and short axes of each egg were measured under a compound microscope with the aid of an ocular micrometer. Because all eggs were prolate spheroid in shape, egg volume $(V)$ was calculated using the formula $V=4 / 3 \pi r_{\mathrm{s}}^{2} r_{1}$, where $r_{\mathrm{s}}$ 
and $r_{1}$ were the radii of the short and long axes of the egg respectively.

To determine egg energy content, 3 subsamples of 20 to 50 eggs from each of 47 spent individuals were randomly selected, briefly washed with distilled water, and used for organic carbon analysis. The measurement of the egg energy content followed the method outlined by Qian \& Chia (1991).

Values for the reproductive characteristics of Capitella sp. recorded in situ were compared with those recorded in the laboratory by a 2 -tailed unpaired $t$-test (Zar 1984).

\section{RESULTS}

\section{Larval abundance}

Plankton sample analyses over 26 mo revealed a distinct annual cycle of larval abundance for Capitella sp. at both Bamfield and Grappler Inlets (Fig. 2). For example, the larval density at Bamfield Inlet during 1987 increased to a maximum of 1130 larvae $\mathrm{m}^{-3}$ in early spring, declined in early summer, but increased again slightly in early autumn. The lowest larval density was recorded in mid or late winter. At Grappler Inlet, fluctuations in larval abundance showed a similar pattern (Kendall's test: $N=26, t=0.619, \mathrm{p}<0.001$ ), but larval density was approximately 1 order of magnitude lower than at Bamfield Inlet.

\section{Recruitment}

At Grappler Inlet, the population density of Capitella $\mathrm{sp}$. reached a peak in midsummer $\left(4700 \mathrm{~m}^{-2}\right)$, declined

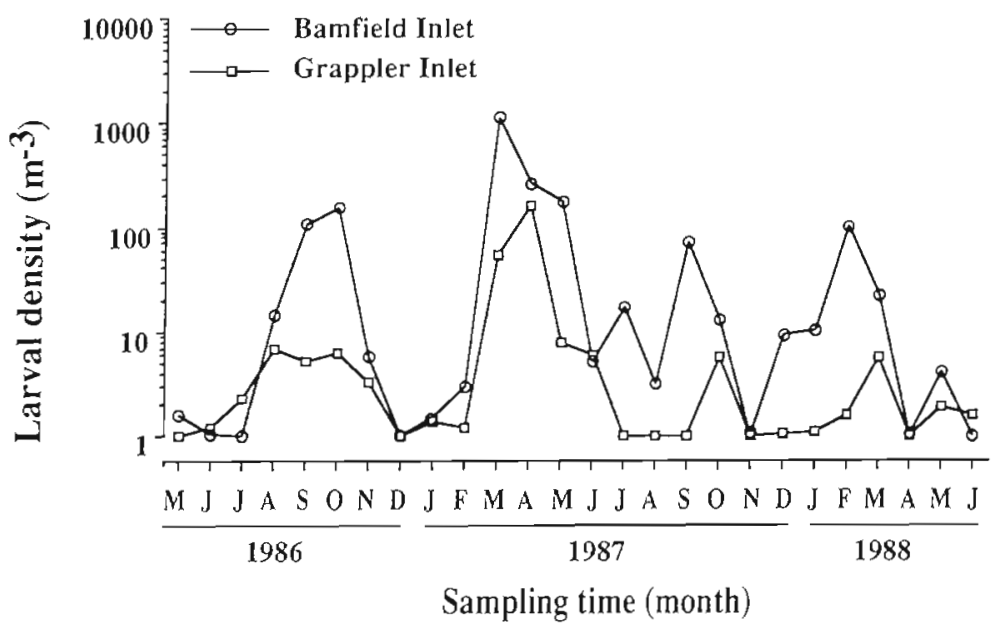

Fig. 2. Capitella sp. Seasonal changes in densities of larvae at Bamfield Inlet and Grappler Inlet

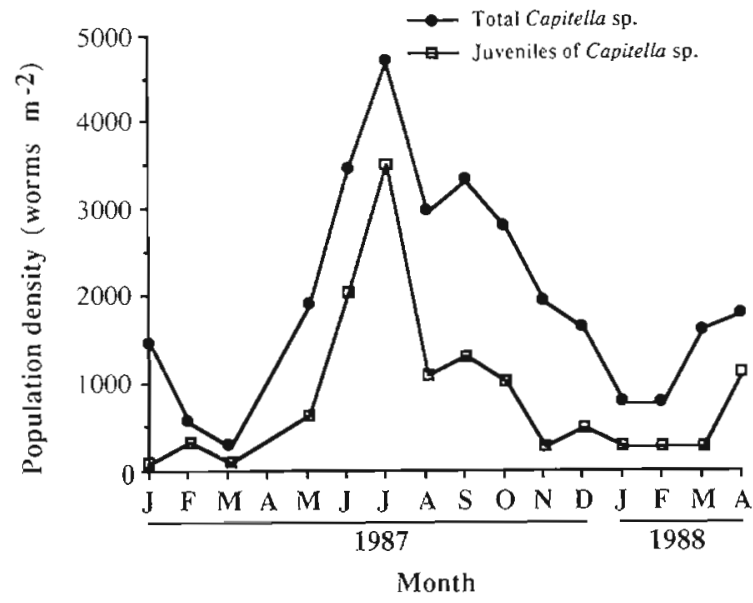

Fig. 3. Capitella sp. Population density and juvenile density at Grappler Inlet

in autumn, and remained low throughout the winter (Fig. 3). This pattern appeared to be correlated with recruitment, as indicated by the high percentage of juveniles found in the benthic samples (see the proportion of juveniles in Fig. 3). For instance, $>50 \%$ of all individuals collected from May to July 1987 were smaller than $10 \mathrm{~mm}^{3}$ and had no visible gonads or genital spines. There were few juveniles found in the population in winter and early spring.

Population dynamics at Bamfield Inlet was not studied because population density at that site was too low for quantitative analysis. We estimated that the population density for most months of the year was less than 100 worms $\mathrm{m}^{-2}$ which was lower than the lowest density at the Grappler Inlet site.

Larvae did settle in our experimental trays placed in the mid-intertidal zone at both sites (Table 1). Although the intensity of recruitment varied from month to month, it was similar for both sites although there was no distinct intertidal population of Capitella sp. at Bamfield Inlet (Table 1).

Other polychaete species, such as Armandia brevis, Polydora spp., and Polynoid spp., were found in the trays at higher densities than Capitella sp. (Table 2). A brevis and Polynoid spp. are epifaunal species while Polydora spp. is an infaunal species. Most individuals found in the trays were newly settled juveniles. From June 10 to June $30,217 \pm 49$ Capitella juveniles $\mathrm{m}^{-2}$ were found in the 6 replicate trays. The recruitment rate $(11$ juveniles $\mathrm{m}^{-2} \mathrm{~d}^{-1}$ ) was similar to that at Grappler Inlet ( 8 ind. $\mathrm{m}^{-2} \mathrm{~d}^{-1}$ ) during the same period. 
Table 1. No. of recruits [mean $\pm \mathrm{SD}(\mathrm{n})]$ and recruitment rates of Capitella sp. in experimental trays in Grappler and Bamfield Inlets

\begin{tabular}{|lcc|}
\hline $\begin{array}{l}\text { Experimental period } \\
\text { (1988) }\end{array}$ & $\begin{array}{c}\text { Total recruits } \\
\text { (ind. } \mathrm{m}^{-2} \text { ) }\end{array}$ & $\begin{array}{c}\text { Recruitment rate } \\
\text { (ind. } \mathrm{m}^{-2} \mathrm{~d}^{-1} \text { ) }\end{array}$ \\
\hline $\begin{array}{l}\text { Grappler Inlet } \\
\text { Apr 14 to May 4 }\end{array}$ & $\begin{array}{l}720 \pm 796(12) \\
\text { May 11 to Jun 2 }\end{array}$ & 34 \\
Jun 13 to Jul 3 & $1182 \pm 661(6)$ & 56 \\
Jul 5 to Jul 26 & $399 \pm 36(12)$ & 8 \\
& & 19 \\
Bamfield Inlet & $917 \pm 520(6)$ & 31 \\
May 10 to Jun 7 & $217 \pm 49(6)$ & 11 \\
Jun 10 to Jun 30 & & \\
\hline
\end{tabular}

Fig. 4A to $\mathrm{C}$ summarizes the size distribution of juveniles collected in the trays at Grappler Inlet from May to August 1988, whereas Fig. 4D, E summarizes the size distribution of juveniles collected in the trays at Bamfield Inlet. The new recruits collected on May 4, 1988 were small. Based on later studies where newly hatched and newly settled juveniles of Capitella sp. with an average body volume of 0.15 to $0.17 \mathrm{~mm}^{3}$ had a growth rate of $0.4 \mathrm{~mm}^{3} \mathrm{~d}^{-1}$ (see Fig. 7), we concluded that approximately $40 \%$ of new recruits (others could be immigrants) with a body volume of less than $1 \mathrm{~mm}^{3}$ must be newly settled juveniles less than 3 wk old. In the samples from June and July, new recruits could be divided into at least 2 or 3 cohorts. Worms larger than $6 \mathrm{~mm}^{3}$ were the oldest and must have settled at the beginning of the experiment. Fig. 4D shows that over $50 \%$ of these new recruits had a body volume $<2 \mathrm{~mm}^{3}$, indicating that they were newly settled juveniles.

\section{Mortality}

The mortality of Capitella sp. in the experimental trays was affected by the size of individuals (Fig. 5; Kruskal-Wallis test: $p<0.05$ ). Fig. 5 shows that there was an exponential relationship between worm size and mortality. The average mortality rate of newly settled juveniles was $3.1 \pm 1.3 \% \mathrm{~d}^{-1}$ for the 3 replicate

Table 2. No. of recruits [mean $\pm \mathrm{SD}(\mathrm{n})]$ and recruitment rates of other polychaetes in experimental trays in the Bamfield Inlet from May 10 to June 7, 1988

\begin{tabular}{|c|c|c|}
\hline Species & $\begin{array}{l}\text { Total recruits } \\
\text { (ind. } \mathrm{m}^{-2} \text { ) }\end{array}$ & $\begin{array}{l}\text { Recruitment rate } \\
\quad \text { (ind. } \mathrm{m}^{-2} \mathrm{~d}^{-1} \text { ) }\end{array}$ \\
\hline Armandia brevis & $6329 \pm 1820(6)$ & 211 \\
\hline Polydora ligni & $4142 \pm 1717(6)$ & 138 \\
\hline Polynoid spp. & $1396 \pm 425$ & 46.5 \\
\hline
\end{tabular}
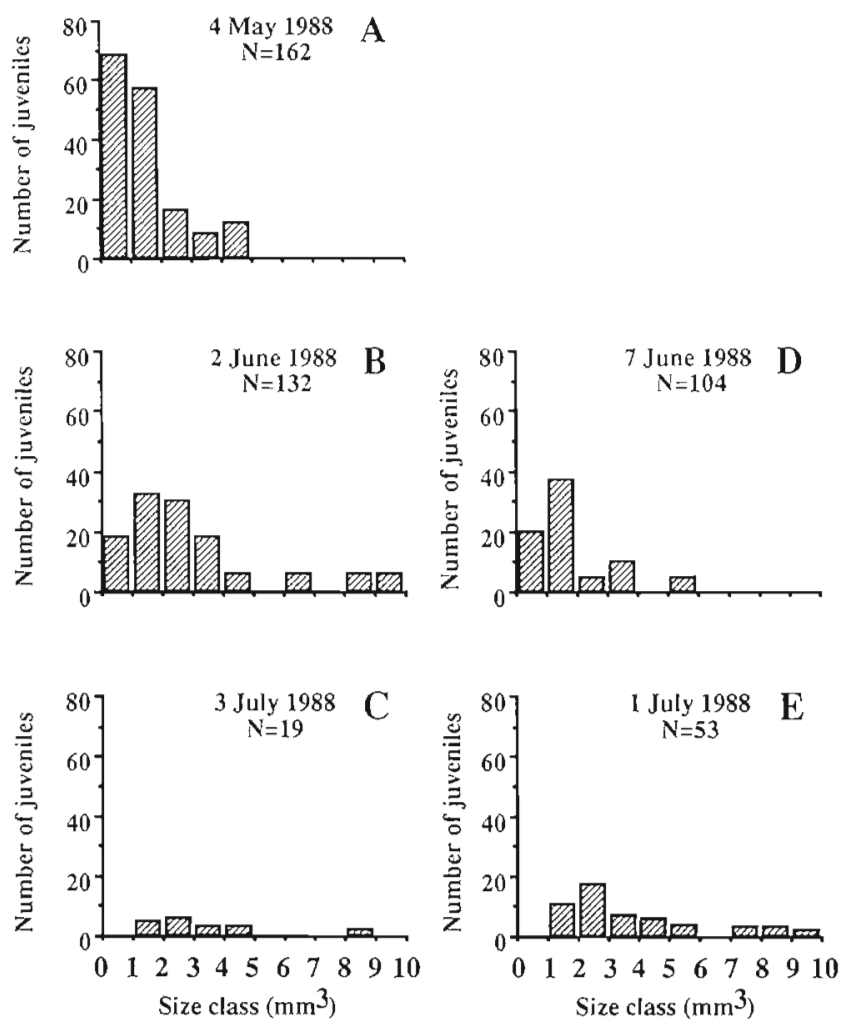

Fig. 4. Capitella sp. Size distribution of newly recruited juveniles in the experimental trays at Grappler Inlet (A to C) and at Bamfield Inlet (D to E)

trays at Grappler Inlet, and $3.0 \pm 0.1 \% \mathrm{~d}^{-1}$ for the 3 replicate trays at Bamfield Inlet (Mann-Whitney test: $p=0.33$ ); the mortality rate of 2 wk old juveniles was $1.48 \pm 0.87 \% \mathrm{~d}^{-1}$ (3 replicate trays) at Grappler Inlet and $1.25 \pm 0.37 \% \mathrm{~d}^{-1}$ (3 replicate trays) at Bamfield Inlet (Mann-Whitney test: $\mathrm{p}=0.096$ ).

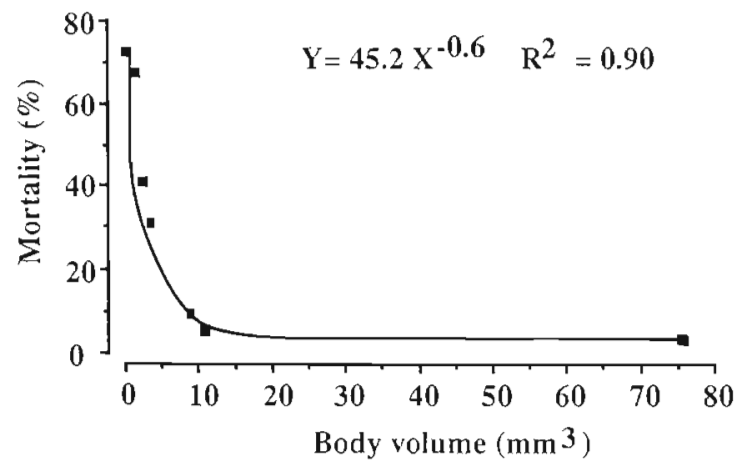

Fig. 5. Capitella sp. Relationship between initial body size and mortality rate at Grappler lnlet. Values plotted are mean mortality for 12 replicate trays (each containing 100 marked worms) 


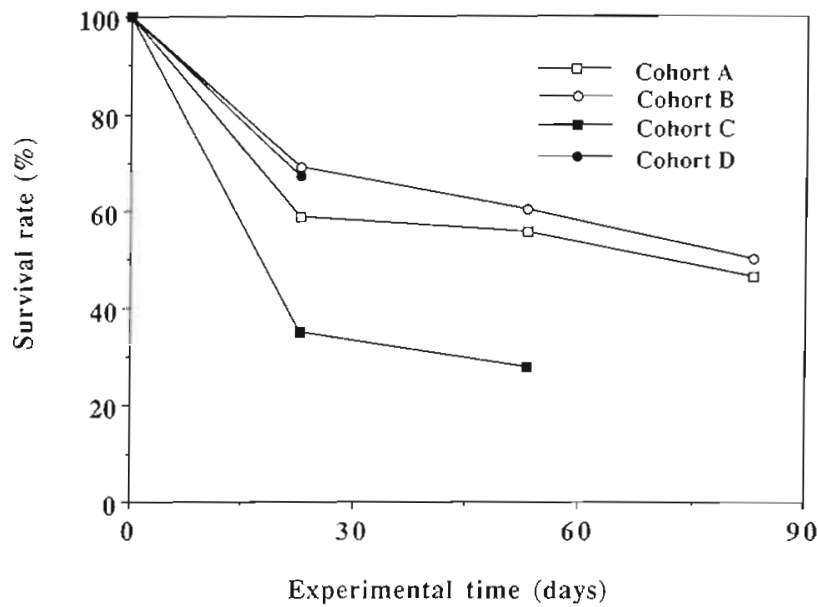

Fig. 6. Capitella sp. Survival rate recorded in the controlled experiments at Grappler Inlet. Cohorts A to D represent the sibling juveniles from 4 different spawnings. Data plotted are average survival rates of 3 replicate trays, each tray starting with 100 marked worms
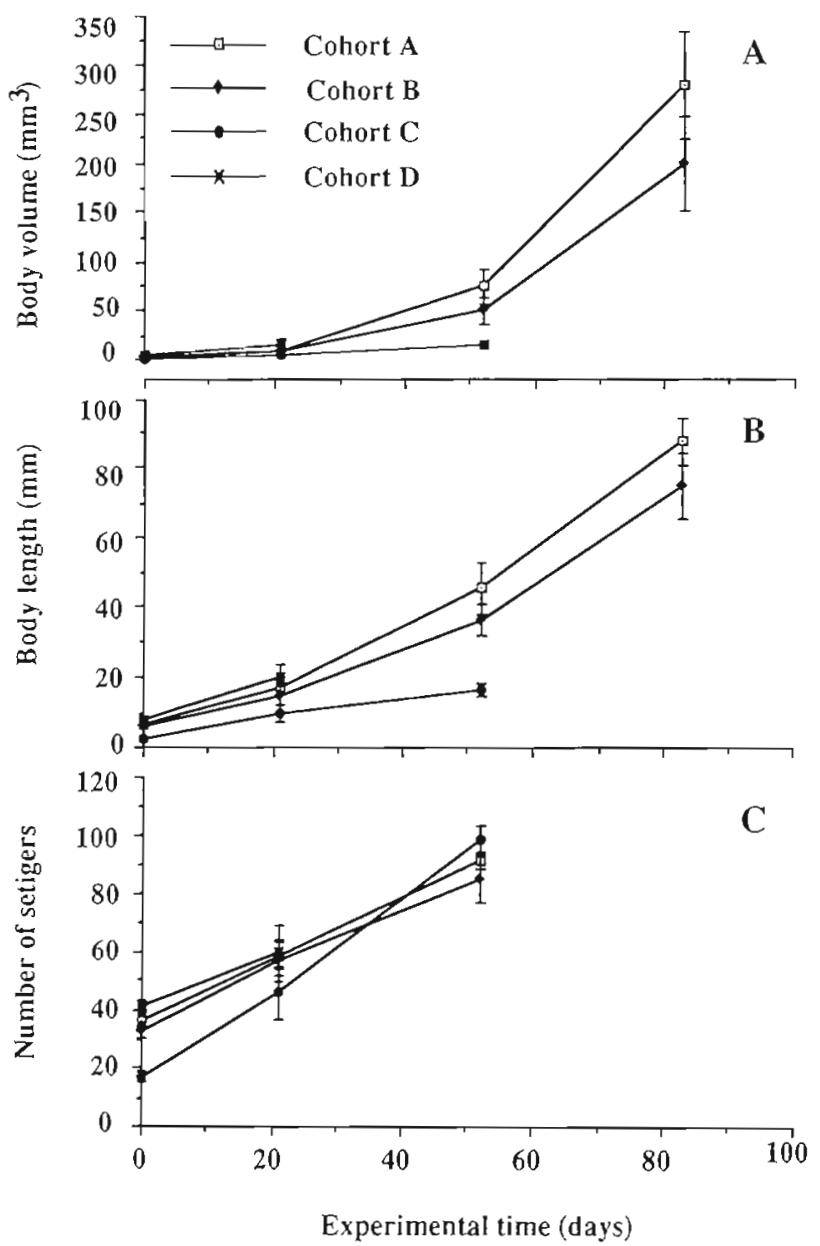

Fig. 7 Capitella sp. Growth measured in the controlled experiments at Grappler Inlet. Cohorts $A$ to $D$ represent the sibling juveniles from 4 different spawnings. Data plotted are mean \pm SD of 30 worms measured for each point

\section{Survival rate of cohorts}

Survival rates of 4 cohorts throughout the experiment are plotted in Fig. 6. Survival rate dropped sharply in the first $3 \mathrm{wk}$ of the experiments but the decline was slower afterward. In addition, survival rates of these 4 cohorts were different during the first period of the experiments. Cohort $\mathrm{C}$ showed a much lower survival rate than the other groups. Due to large difference in initial body size of the experimental worms and large variation among the experimental trays within each cohort, comparison of survivorship curves of 4 groups was not attempted.

\section{Growth}

The body length, volume, and number of setigers of siblings of 4 cohorts increased throughout the experimental period (Fig. 7A to C). The growth rate (body volume increase per day) was significantly correlated with the worm's initial size (Fig. 8). For instance, the increase in the body size of newly settled juveniles (cohort C) was $8.5 \%$ of worm size per day. Growth rate (body volume increase per day) decreased once the individuals began to develop gametes, although worms continued to grow until spawning.

\section{Impact of predation on juvenile mortality}

The presence of predators had significant effects on juvenile mortality of Capitella sp. Juvenile mortalities in trays with or without predators were easily ranked as follows: controls < trays with substratum from the Grappler Inlet $<$ trays with substratum of the Bamfield Inlet (Fig. 9; 1 -way ANOVA: $F_{2,9}=328, \mathrm{p}<0.0001$ ). Our results also revealed that (1) the mud from the Bamfield Inlet that was placed in the experimental trays

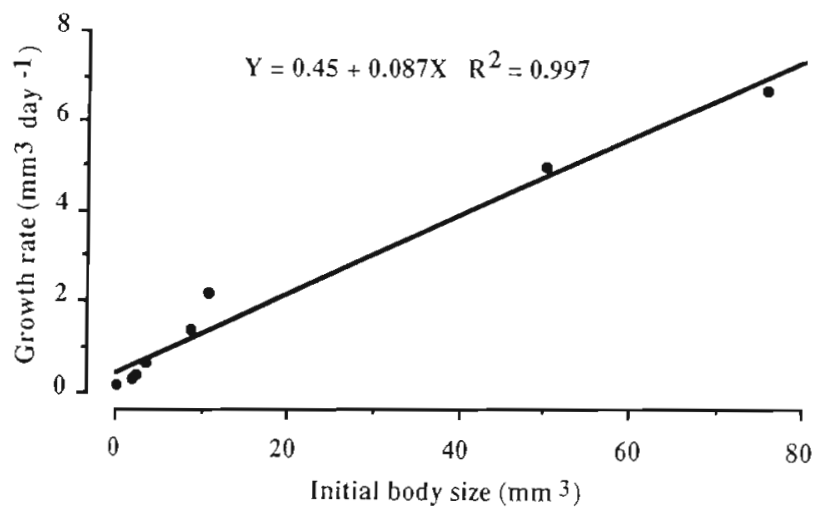

Fig. 8. Capitella sp. Relationship between initial body size and growth rate (dally net increase in body volume) measured in situ 


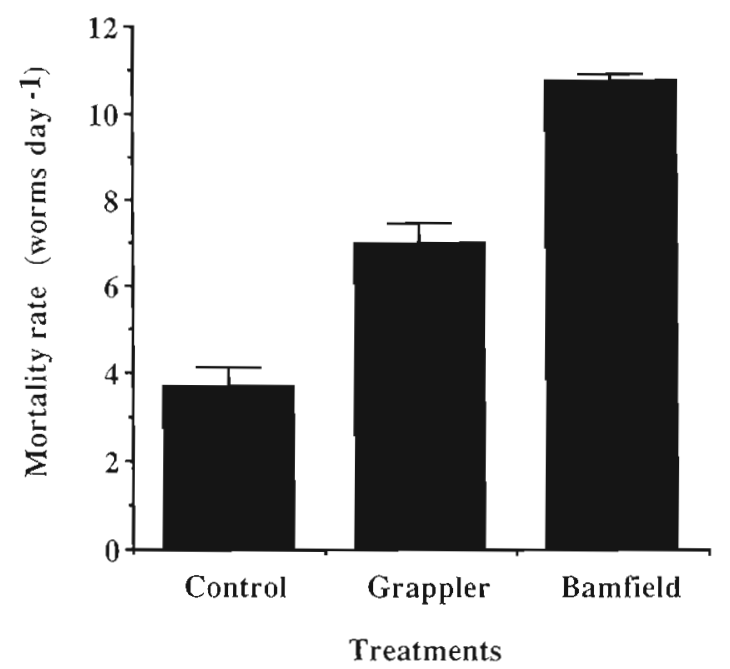

Fig. 9. Capitella sp. Mean mortality rate of marked juveniles measured in situ within $9 \mathrm{~d}$. Values plotted are means \pm SD for 4 replicate experimental trays (each starting with 100 juveniles). Control: tray with all predators excluded; Grappler. tray with mud from Grappler Inlet, all predators retained, Bamfield: tray with mud from Grappler Inlet, all predators retained

contained more infauna and epifauna predators than the mud from the Grappler Inlet (Fig 10) and (2) mortality rate of the marked juveniles placed in the experimental trays in situ increased with increased numbers of predators (Fig. 11).

\section{Fecundity, egg size, and egg energy content}

Individuals of cohorts $\mathrm{A}$ and $\mathrm{B}$ in the experimental trays reached sexual maturity within $2.5 \mathrm{mo}$. By July 3 , 1988, of 162 individuals, 12 were males, 3 were hermaphrodites, and the rest were females. By July 27,42 females released eggs with an average volume of $7.3 \pm$ $0.01 \times 10^{-3} \mathrm{~mm}^{3} \mathrm{egg}^{-1}$. The average dimensions of these eggs were $269 \pm 32.1 \mu \mathrm{m}$ and $227 \pm 24.4 \mu \mathrm{m}$ for the long and short axes respectively. The average egg energy content was $88 \pm 9.5 \mu \mathrm{J} \mathrm{egg}{ }^{-1}$. In terms of the number of eggs produced in the first spawn, the average fecundity of the 42 females was $764 \pm 207$ (range: 322 to 1172). Eggs in the tubes of some worms developed into larvae that emerged from the tube and swam close to the bottom of the culture beaker for about $24 \mathrm{~h}$ prior to settling. Newly settled juveniles from these larvae did not differ in either size or morphological features from the juveniles metamorphosed inside the tube.

Table 3 summarizes fecundity, egg size, egg energy content, and total energy invested in eggs of the sibling individuals reared in experimental trays in situ and those reared in laboratory experiments using dif-

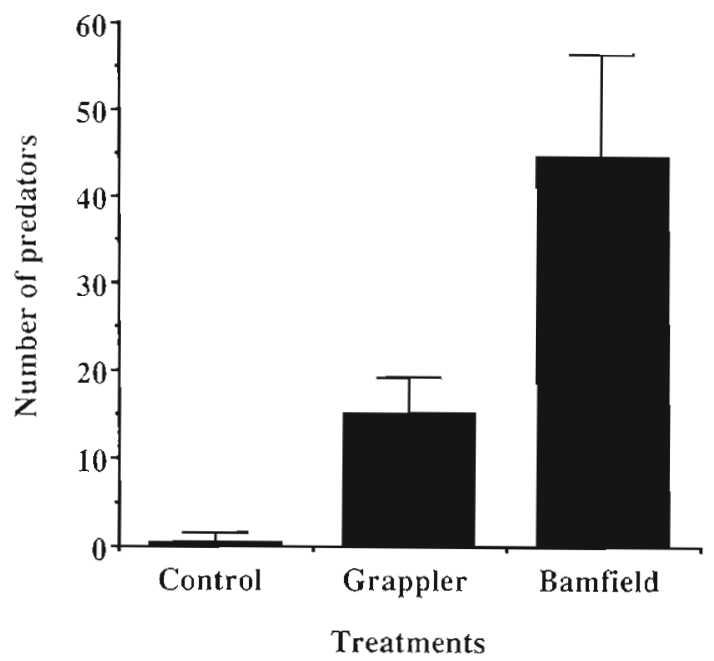

Fig. 10. Predator abundance in the experimental trays recorded after $9 \mathrm{~d}$. Values plotted are means \pm SD for 4 replicate experimental trays (each starting with 100 juvenile Capitella sp.). Control: tray with all predators excluded; Grappler: tray with mud from Grappler Inlet, all predators retained; Bamfield: tray with mud from Grappler Inlet, all predators retained

ferent food rations. Fecundity, egg energy content, and total energy invested in spawned eggs were similar between field-reared and laboratory-reared worms whereas egg size was significantly different (see $t$-test results in Table 3). For both groups, great variations in reproductive characteristics were recorded.

Among the spawned individuals, 5 females produced very small eggs with an average volume of

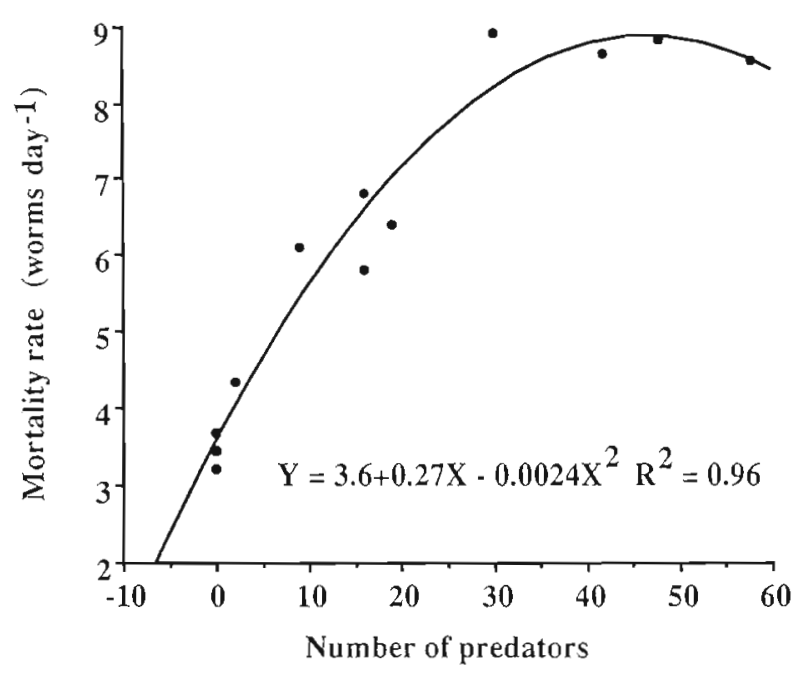

Fig. 11. Capitella sp. The relationship between juvenile mortality measured in situ within $9 \mathrm{~d}$ and predator abundance in the experimental trays. All trays were placed in the middle intertidal zone of Bamfield Inlet 
Table 3. Capitella sp. Comparison of the reproductive characteristics between worms measured in the laboratory and those measured in situ with results of 2 -talled unparred $t$-tests

\begin{tabular}{|c|c|c|c|c|c|c|c|c|}
\hline \multirow[t]{2}{*}{ Parameter } & \multicolumn{3}{|c|}{ In situ } & \multicolumn{3}{|c|}{ Lab } & \multicolumn{2}{|c|}{$t$-test } \\
\hline & Mean & Range & $\mathrm{n}$ & Mean & Range & $\mathrm{n}$ & $t$ & p \\
\hline Fecundity (no. of eggs) & 764 & $(332-1.172)$ & 42 & 651 & $(269-1342)$ & 138 & 1.3 & $>0.05$ \\
\hline Egg volume $\left(\mathrm{mm}^{3} \times 10^{-3}\right)$ & 7.3 & $(5.5-10.1)$ & 220 & 14.5 & $(9.7-18.4)$ & 1280 & 11.2 & $<0.001$ \\
\hline Long axis ( $\mu \mathrm{m})$ & 269 & $(220-314)$ & 220 & 318 & $(245-378)$ & 1280 & 2.9 & $<0.05$ \\
\hline Short axis $(\mu \mathrm{m})$ & 227 & $(196-266)$ & 220 & 285 & $(216-322)$ & 1280 & 3.9 & $<0.001$ \\
\hline Energy content $\left(\mu \mathrm{J} \mathrm{egg}^{-1}\right)$ & 88 & $(66-108)$ & $27^{\mathrm{a}}(3)^{\mathrm{b}}$ & 87 & $(53-124)$ & $138^{\mathrm{a}}(3)^{\mathrm{b}}$ & 0.7 & $>0.05$ \\
\hline Total energy content of spawned eggs ( $\mathrm{J}$ ind. $\left.{ }^{-1}\right)$ & 62 & $(29.2-103.1)$ & 42 & 54 & $(19.8-109.6)$ & 138 & 1.7 & $>0.05$ \\
\hline Generation time (d) & & 95 & & & 116 & & - & - \\
\hline
\end{tabular}

$0.63 \pm 0.40 \times 10^{-3} \mathrm{~mm}^{3}(\mathrm{n}=60)$. The average dimensions of those eggs were $104.3 \pm 23.3 \mu \mathrm{m}$ for the long axis and $103.7 \pm 22.5 \mu \mathrm{m}$ for the short axis. The average first spawn fecundity of the 5 worms was $6890 \pm 3116$ eggs and the egg energy content of the small eggs was $8.58 \pm 1.56 \mu \mathrm{J} \mathrm{egg}^{-1}$. As juveniles used for these field experiments were all siblings of a single spawning of a single worm, what triggered these 5 individuals to switch their reproductive mode remains unknown.

\section{DISCUSSION}

In this study, we found that larval abundance at Bamfield Inlet was about 10 times higher than that at Grappler Inlet, while the population density of Capitella sp. at Grappler Inlet was much higher than that at Bamfield Inlet. Our survey of the intertidal population of Capitella sp. conducted in different seasons showed that there were no other distinctive intertidal populations in either inlet except those studied. We believe that there must have been some subtidal populations of Capitella sp. in Bamfield Inlet that contributed to the high larval abundance of our site, but underwater surveys of the subtidal mudflat have been unable to find them. Further investigation is thus needed to determine the source of larvae in Bamfield Inlet.

Although larval abundance, distribution, settlement, juvenile mortality, generation time, and reproductive characteristics can all influence the population dynamics of benthic invertebrates, any one of these factors may play a dominant role in a given habitat. Our field experiments demonstrated that recruitment in experimental trays at Grappler Inlet was not significantly different from that at Bamfield Inlet, although larval abundance at Bamfield Inlet was 1 order of magnitude higher than that at Grappler Inlet. The study also showed that the abundance of larvae in plankton did not contribute to intertidal population dynamics (an- nual cycle of population density), since field surveys demonstrated that population density of Capitella sp. at Bamfield Inlet stayed very low year-round regardless of changes in larval density. We thus concluded that larval abundance in plankton was not a determining factor of the population dynamics of intertidal Capitella sp. in our study area.

As our experiment indicated, some individuals of Capitella sp. in the experimental trays produced large eggs that developed into large larvae of short larval life span. In our monthly samples collected from the Grappler Inlet site, there were always some individuals that contained large eggs in the ovaries. This suggests that benthic larval production may be very important in determining population dynamics. Unfortunately, benthic larval production is very difficult to quantify and has not been documented in previous studies.

Our results revealed (1) the predator density in the mud from Bamfield Inlet was 2 times higher than that in the mud from Grappler Inlet, (2) the mortality rate of marked juveniles placed in the experimental trays with the mud from Bamfield Inlet was higher than that in the trays with the mud from Grappler Inlet, and (3) there was a clear relationship between juvenile mortality and predator abundance. We conclude that differential mortality of juveniles is the major factor affecting the population density of Capitella sp. at the 2 sites. We suggest that although larvae were able to settle at Bamfield Inlet, juveniles could not survive long enough to establish a detectable density of population (i.e. they did not reach a size large enough for quantitative sampling) due to high predation pressure. This agrees with the results of many previous studies of other polychaetes (Woodin 1981, 1982, 1984, 1985, Ambrose 1984a, b, 1986, Chesney \& Tenore 1985, Zajac 1986, Beukema 1987). At Bamfield Inlet, the polychaete community was dominated by suspensionand deposit-feeding spionids which could prey on post-settling stages of Capitella sp.. At Grappler Inlet, 
major infaunal predators of Capitella sp. included Nereis virense and Glycera americana, preying on both newly settled juveniles and even adults of Capitella sp. Since density of these predators remained very low year-round, however, they may play a less important role in controlling population dynamics at this site. In addition, Rumrill (1987) found that asteroid larvae in Bamfield Inlet are exposed to a greater risk than those in Grappler Inlet due to differences in the type and number of suspension feeders.

The field experiments in this study demonstrated that mortality was age- or size-dependent for Capitella sp. Over $90 \%$ of newly settled juveniles were lost in the period up to 14 to $21 \mathrm{~d}$ after settlement. The mortality of young juveniles with a body volume of $<3 \mathrm{~mm}^{3}$ was about $65 \%$, and worms with a body volume $>10 \mathrm{~mm}^{3}$ had a mortality rate of less than $5 \%$ during the same period. A similar trend has been recorded for Balanus glandula in a recent in situ study of postsettling mortality of intertidal barnacles (Qian \& Gosselin unpubl.)

This study is the first to mark and recapture infaunal polychaetes and measure their growth in situ. The growth rates of different-sized Capitella sp. recorded in the field in this study were quite similar to those of siblings cultured in the laboratory on dried ground Ulva spp. (2 $\mathrm{mg} \mathrm{\textrm {d } ^ { - 1 }}$ worm $^{-1}$; Qian 1991), but were lower than those of Tenore \& Chesney (1985). In their experiments, Tenore \& Chesney (1985) recorded maximum daily individual growth rates of 21,19 , and $15 \%$ for small, medium, and large $C$. capitata. The lower growth rates of this experiment compared to Tenore \& Chesney (1985) may be due to lower ambient temperature; interstitial seawater temperature at our sites was always below $16^{\circ} \mathrm{C}$ while Tenore \& Chesney's work was carried out at $20^{\circ} \mathrm{C}$. The food availability at the sites could also be the factor influencing growth rate as previous studies have indicated that growth of both the juvenile and adult of Capitella spp. are affected directly by food rations (Grémare et al. 1989, Qian 1991, Qian \& Chia 1991). The net increase in body volume is also size-dependent since large individuals had higher net increases. In other words, within a given growth period, the larger individuals grew more (net increase) than the smaller individuals. This indicates that slight differences in spawning time or settling time may result in cohorts of different sizes.

The results of this study show that variations in the reproductive characteristics of Capitella sp. recorded in laboratory experiments (Table 3; Qian 1991, Qian \& Chia 1991, 1992a, b) are supported by field observations. Sibling individuals kept in the same experimental tray showed large differences in fecundity or produced eggs of different sizes with different energy contents. The large variations in reproduction and growth of Capitella sp. should therefore be adaptive to accommodating whole sets of environmental conditions. The uncertainty in environmental conditions may act as a driving force in the evolution of lifehistory traits of Capitella sp. It has been reported that opportunistic polychaete species (e.g. C. Capitata, Polydora ligni, Streblospio benedicti) share many characteristics, including high flexibility in reproduction and growth, high sensitivity to environmental changes, and a great potential for converting energy into reproductive output (Levin \& Creed 1986, Levin et al. 1987, 1991, Levin \& Huggett 1990).

It should be pointed out, however, that the growth rate and reproductive characteristics measured from worms reared in the experimental trays may also deviate from those found in natural environments. Marking worms and releasing them into experimental trays placed in the field can at least provide some much needed information on population dynamics.

Acknowledgements. We thank Dr J. McInerney, Director of Bamfield Marine Station, for providing us with laboratory space and access to facilities. Dr A. Martel assisted in constructing experimental trays and in sampling. We are grateful to 3 anonymous reviewers for their valuable comments on the manuscript and to Raymond Dragan for proofreading a later version. This work was supported by National Sciences Engineering Research Council grants to F.S.C. and a Killam Postdoctoral Fellowship from the University of British Columbia to P.Y.Q. P.Y.Q was also supported by the Hong Kong University of Science and Technology while writing the manuscript.

\section{LITERATURE CITED}

Ambrose, W. G. Jr (1984a). Influences of predatory polychaetes and epibenthic predators on the structure of a soft-bottom community in a Maine estuary. J. exp. mar. Biol. Ecol. 81. 115-145

Ambrose, W. G. Jr (1984b). Role of predatory infauna in structuring marine soft-bottom communities. Mar. Ecol. Prog. Ser. 17: 109-115

Ambrose, W. G. Jr (1986). Estimate of removal rate of Nereis virens (Polychaeta: Nereidae) from an intertidal mudflat by gulls (Larus spp.). Mar. Biol. 90: 243-247

Beukema, J. J. (1987). Influence of the predatory polychaete Nephtys hombergii on the abundance of other polychaetes. Mar. Ecol. Prog. Ser. 40: 95-101

Chesney, E. J., Tenore, K. R. (1985). Effects of predation and disturbance on the population growth and dynamics of the polychaete Capitella capitata (Type I). Mar. Biol. 85: 77-82

Commito, J. A. (1982). Importance of predation by infaunal polychaetes in controlling the structure of a soft-bottom community in Maine, USA. Mar. Biol. 68: 77-81

Gallagher, E. D., Jumas, P. A., Trueblood, D. D. (1983). Facilitation of soft-bottom benthic succession by tube builders. Ecology 64: 1200-1216

Grémare, A., Marsh, A. G., Tenore, K. R. (1989). Secondary production and reproduction of Capitella capitata type I (Annelida: Polychaeta) during a population cycle. Mar. Ecol. Prog. Ser. 51: 99-105 
Kent, A. D., Day, R. W. (1983). Population dynamics of an infaunal polychaete: the effect of predators and an adultrecruit interaction. J. exp. mar. Biol. Ecol. 73: 185-203

Levin, L. A. (1981). Dispersion, feeding behavior and competition in two spionid polychaetes. J. mar. Res. 39: 99-117

Levin, L. A., Creed, E. L. (1986). Effect of temperature and food availability on reproductive responses of Streblospio benedicti (Polychaeta: Spionidae) with planktotrophic or lecithotrophic development. Mar. Biol. 92: 103-113

Levin, L. A., Caswell, H., DePatra, K. D., Creed, E. L. (1987). Demographic consequences of larval development mode: planktotrophy vs. lecithotrophy in Streblospio benedicti. Ecology 68: 1877-1886

Levin, L. A., Huggett, D. V. (1990). Implications of alternative larval development modes for the seasonal dynamics and demography of an estuarine polychaete. Ecology 71 : $2191-2208$

Levin, L. A., Zhu, J., Creed, E. (1991). The genetic basis of life-history characters in a polychaete exhibiting planktotrophy and lecithotrophy. Ecology 45(2): 380-397

Luckenbach, M. (1984). Settlement and early post-settlement survival in the recruitment of Mulinia lateralis (Bivalvia). Mar. Ecol. Prog. Ser. 17: 245-250

Oliver, J. S., Slattery, P. N. (1985). Effects of crustacean predators on species composition and population structure of soft-bodied infauna from McMurdo Sound, Antarctica. Ophelia 24: 155-175

Qian, P. Y (1991). Impact of environmental factors on lifehistory strategies of the marine polychaete worm Capitella sp. Ph.D. thesis, Univ. of Alberta, Edmonton

Qian, P. Y., Chia, F. S. (1991). Fecundity and egg size of Capitella sp.were mediated by diet. J. exp. mar. Biol. Ecol. 148: 11-25

Qian, P. Y., Chia, F. S. (1992a). Effects of aging on fecundity, egg size and energy content, and reproductive output of Capitella sp. J. exp. Mar. Biol. Ecol. 156: 23-38

Qian, P. Y., Chia, F. S. (1992b). Effects of diet type on the demographics of Capitella sp. (Annelida: Polychaeta): Iecithotrophic development versus planktotrophic development. J. exp. mar. Biol. Ecol. 157: 159-179

Rumrill, S. S. (1987). Differential predation upon embryos and larvae of temperate Pacific echinoderms. Ph.D thesis,

This article was submitted to the editor
Univ of Alberta, Edmonton

Tamaki, A. (1985). Inhibition of larval recruitment of Armandia sp. (Polychaeta: Opheliidae) by established adults of Pseudopolydora paucibranchiata (Okuda) (Polychaeta: Spionidae) on an intertidal sand flat. J. exp. mar. Biol. Ecol. 87: 67-82.

Tenore, K. R. (1981). Organic nitrogen and caloric content of detritus. 1 Utilization by the deposit-feeding polychaete, Capitella capitata. Estuar. coast. Shelf Sci. 12: $39-47$

Tenore, K. R. (1983). Organic nitrogen and caloric content of detritus. 3. Effect on growth of a deposit-feeding polychaete, Capitella capitata. Estuar. coast. Shelf Sci. 17: $733-742$

Tenore, K. R., Chesney, E. J. Jr (1985). The effects of interaction of rate of food supply and population density on the bioenergetics of the opportunistic polychaete, Capitella capitata (Type I). Limnol. Oceanogr. 30: 1188-1195

Watzin, M. C. (1986). Larval settlement into marine soft-sediment systems: interactions with the meiofauna. J. exp. mar. Biol. Ecol. 98: 65-113

Williams, J. G. (1980). The influence of adults on the settlement of spat of the clam Tapes japonica. J. mar. Res. 38 . $729-741$

Woodin, S. A. (1981). Disturbance and community structure in a shallow water sand flat. Ecology 62: 1052-1066

Woodin, S. A. (1982). Browsing: important in marine sedimentary environments? Spionid polychaete examples. J. exp. mar. Biol. Ecol. 60: 35-45

Woodin, S. A. (1984). Effects of browsing predators: activity changes in infauna following tissue loss. Biol. Bull. 166: $558-573$

Woodin, S. A. (1985). Effects of defecation by arenicolia polychaete adults on spionid polychaete juveniles in field experiments: selective settlement or differential mortality. J. exp. mar. Biol. Ecol. 87: 119-132

Zajac, R. N. (1986). The effects of intra-specific density and food supply on growth and reproduction in an infaunal polychaete Polydora ligni Webster. J. mar. Res. 44: $339-359$

Zar, J. H. (1984). Biostatistical analysis, 2nd edn. PrenticeHall, Englewood Cliffs, $\mathrm{NJ}$

Manuscript first received: January 25, 1994

Revised version accepted: May 31, 1994 